This PDF is a selection from a published volume from the National Bureau of Economic Research

Volume Title: Managing Currency Crises in Emerging Markets

Volume Author/Editor: Michael P. Dooley and Jeffrey A.

Frankel, editors

Volume Publisher: University of Chicago Press

Volume ISBN: 0-226-15540-4

Volume URL: http://www.nber.org/books/dool03-1

Conference Date: March 28-31, 2001

Publication Date: January 2003

Title: IMF and World Bank Structural Adjustment Programs and Poverty

Author: William Easterly

URL: http://www.nber.org/chapters/c9656 


\title{
IMF and World Bank Structural Adjustment Programs and Poverty
}

\author{
William Easterly
}

Poverty reduction is in the news for both the International Monetary Fund (IMF) and the World Bank. The IMF website says:

In September 1999, the objectives of the IMF's concessional lending were broadened to include an explicit focus on poverty reduction in the context of a growth oriented strategy. The IMF will support, along with the World Bank, strategies elaborated by the borrowing country in a Poverty Reduction Strategy Paper (PRSP).

For its part, the World Bank headquarters has built into its lobby wall the slogan "our dream is a world free of poverty." In a joint statement issued by the President of the World Bank and the Managing Director of the International Monetary Fund in April 2001, they declared poverty "the greatest challenge facing the international community" and an issue concerning which "the Bank and Fund have an important role to play" (World Bank and International Monetary Fund 2001, 2).

The recent East Asian currency crisis and its aftershocks in other countries generated intense concern about how the poor were faring under structural adjustment programs supported by the Bank and the IMF. The poverty issue is so red-hot that IMF and World Bank staff began to feel that

William Easterly is senior advisor of the Development Research Group at the World Bank.

Views expressed here are not necessarily those of the World Bank. The author is grateful to Martin Ravallion and Shaohua Chen for making their poverty spells database available. He is also grateful for discussions with Paul Collier, David Dollar, Peter Lanjouw, and Martin Ravallion, for several rounds of discussion with discussant Ted Truman, and for comments by Anders Aslund, Ricardo Hausmann, Nora Lustig, Aart Kraay, Michael Kremer, Sergio Schmukler, and John Williamson and by participants in the NBER pre-conference, the first annual IMF research conference, and the NBER conference. Any remaining errors are the responsibility of the author alone. 
every action inside these organizations, from reviewing public expenditure to vacuuming the office carpet, should be justified by its effect on poverty reduction.

At the same time, there has been a long-standing criticism from the left of World Bank and IMF structural adjustment programs as disproportionately hurting the poor:

When the International Monetary Fund (IMF) and World Bank arrive in southern countries, corporate profits go up, but so do poverty and suffering. Decades of promises that just a little more "short-term" pain will bring long-term gain have exposed the IMF and World Bank as false prophets whose mission is to protect those who already control too much wealth and power.

A report published today by the World Development Movement (WDM) shows that the International Monetary Fund's (IMF) new Poverty Reduction Strategies are acting as barriers to policies benefiting the world's poorest people.

Many developing countries suffered . . . sustained increases in prosperity, accompanied by dramatic increases in inequality and child poverty ... under the auspices of IMF and World Bank adjustment programmes.

In country after country, structural adjustment programs (SAPs) have reversed the development successes of the 1960s and 1970s, with . . millions sliding into poverty every year. Even the World Bank has had to accept that SAPs have failed the poor, with a special burden falling on women and children. Yet together with the IMF it still demands that developing countries persist with SAPs.

This paper examines the effect of IMF and World Bank adjustment lending on poverty reduction. ${ }^{1}$ I briefly examine the effect of IMF and World Bank adjustment lending on growth and find no effect (suitably instrumenting for adjustment lending), which is in line with the previous long and inconclusive literature. My main result is that IMF and World Bank adjustment lending lowers the growth elasticity of poverty, that is, the amount of change in poverty rates for a given amount of growth. This means that economic expansions benefit the poor less under structural adjustment, but at the same time economic contractions hurt the poor less. What could be the mechanisms for such a result?

There could be several possible explanations. I first speculate that IMF and World Bank conditionality may be less austere when lending occurs during an economic contraction, whereas conditionality may require more macro adjustment during an expansion. If macro adjustment dispropor-

1. I follow the convention of using adjustment lending, structural adjustment, structural adjustment lending, and structural adjustment programs as interchangeable terms. Later I distinguish between structural adjustment lending and structural adjustment policies. 
tionately hurts the poor - say, because fiscal adjustment, for example, is implemented through increasing regressive taxes like sales taxes or decreasing progressive spending like transfers - then we get the result that IMF and World Bank adjustment lending lowers the growth elasticity of poverty. Adjustment lending could even include an explicit fiscal insurance mechanism, such as an increase in subsidies, that cushions the effect of contractions on the poor but is accompanied by a reduction in subsidies in times of expansion. We can test this hypothesis explicitly by evaluating the behavior of fiscal policy and macro policy variables during expansions and contractions, with or without adjustment lending.

A nearly opposite hypothesis is that IMF and World Bank conditionality may itself cause an expansion or contraction in aggregate output - depending on the composition of the structural adjustment package - but not affect the poor very much. This view would see the poor as mainly deriving their income from informal sector and subsistence activities, which are not affected much by fiscal policy changes or adjustments in macro policies. Structural adjustment packages usually imply that some previously favored formal-sector activities must contract while other formal-sector activities newly favored can expand. The net effect may be overall contraction or expansion, depending on the initial sizes of the declining and expanding sectors and the specific policy measures in the structural adjustment package. However, if the poor are not tightly linked to either the expanding or the contracting formal sector, then the amount of poverty change for a given amount of output change may not be very high under structural adjustment. An expansion or contraction in the absence of adjustment lending, on the other hand, may reflect economy-wide factors that lift or sink all boats.

IMF and World Bank adjustment programs typically force the government to make adjustments in a few highly visible macroeconomic indicators, which again affect mainly the formal sector. On the other hand, a home-grown reform program (for example, that of China over the last two decades, with only three adjustment loans in the 1980s and none in the 1990s) would generally include a more sweeping transformation of incentives that affect the formal and informal sectors alike.

\subsection{Data and Concepts for Paper}

I have data for 1980-98 on all types of IMF lending and on World Bank adjustment lending. International Monetary Fund lending includes standbys, extended arrangements, Structural Adjustment Facilities, and Enhanced Structural Adjustment Facilities (recently renamed Poverty Reduction and Growth Facilities). The latter two kinds of operations are concessional for low-income countries. World Bank adjustment lending includes structural adjustment loans, sectoral structural adjustment loans, 
and structural adjustment credits (the latter is concessional for low-income countries). The data are reported in the year that the loans are approved. Hence, my data take the form of a number of new World Bank and IMF adjustment loans approved each year. For any time period I consider in this paper, I consider the average number of new World Bank and IMF adjustment loans per year.

Conditionality associated with these loans is well known: macroeconomic conditions like reduced budget deficits, devaluation, and reduced domestic credit expansion, and structural conditions like freeing controlled prices and interest rates, reducing trade barriers, and privatizing state enterprises. Although the IMF is associated more with the former and the World Bank with the latter, in practice neither will proceed with an adjustment loan unless the other is satisfied with progress on its area of responsibility. Of course, there will be variation across adjustment loans in exactly what policy conditions are imposed, but it is still an interesting question to ask what the impact of adjustment lending is on average - just as innumerable IMF and World Bank internal studies have done.

For data on poverty, I use an updated version of Ravallion and Chen's (1997) database on poverty spells. These authors were careful to choose spells and countries for which the definition of poverty was constant and comparable over time and across countries. The source of the data is household surveys. They report the proportion of the population that is poor at the poverty line of $\$ 2$ per day at the beginning of and the end of the spell (they also report the poverty rates for a poverty line of $\$ 1$ per day, but I choose to use the former because many countries have a zero initial value at $\$ 1$ per day). They also report the Gini coefficients at the beginning and the end and the mean income in the household survey at the beginning and the end. They report data on 155 spells for sixty-five developing countries (table 11.1 gives the countries and numbers of spells for each). The spells are quite short (median length three years), so I interpret them more as cyclical fluctuations in mean consumption and poverty rather than as long-run tendencies in growth and poverty reduction. Table 11.1 gives the descriptive statistics for all the data.

Descriptive Statistics on Variables Used

\begin{tabular}{lccccc}
\hline & $\begin{array}{c}\text { Change in } \\
\text { Poverty }\end{array}$ & $\begin{array}{c}\text { Mean } \\
\text { Consumption } \\
\text { Growth }\end{array}$ & $\begin{array}{c}\text { Initial } \\
\text { Gini }\end{array}$ & $\begin{array}{c}\text { Initial } \\
\text { Poverty } \\
\text { Rate }\end{array}$ & $\begin{array}{c}\text { Adjustment } \\
\text { Loans } \\
\text { Year }\end{array}$ \\
\hline Mean & $6.0 \%$ & $-1.1 \%$ & 39.5 & 41.2 & 0.62 \\
Median & $-0.1 \%$ & $0.0 \%$ & 39.5 & 36.3 & 0.50 \\
Std. dev. & $31.5 \%$ & $11.1 \%$ & 11.1 & 29.6 & 0.60 \\
$N$ & 149 & 155 & 155 & 154 & 150 \\
\hline
\end{tabular}




\subsection{Results on Adjustment Lending and Poverty Reduction}

Following Ravallion (1997), I regress the change in poverty rate on growth of mean income and the interaction of growth of mean income with the Gini coefficient. The idea of this specification is that if the poor have a low share in existing income (high Gini), they will likely have a low share in newly created income (low growth elasticity of poverty reduction). I also include the level of the initial Gini for completeness. To test the effect of IMF and World Bank adjustment lending, I include the variable measuring number of adjustment loans per year during the poverty spell and also interact this variable with growth.

There is the well-known selection bias problem with World Bank and IMF lending. This lending goes to countries that are in trouble, and this trouble could include initial high poverty rates. We could even imagine that World Bank and IMF programs go to countries that are more likely to reduce poverty rapidly. With these concerns in mind, I instrument for World Bank and IMF lending. I follow the practice of the foreign aid literature in using dummies that measure friends of influential donors, including a dummy for Central America, one for Egypt, and one for Franc Zone countries. I also include continent dummies as instruments for lending, because both the World Bank and IMF have a different department for each continent, and these different departments may have different propensities to make loans. I also include initial income as an instrument of adjustment loan frequency.

With the same set of instruments, I also tested the direct effect of adjustment lending on growth, not controlling for any other factors. In line with a long and inconclusive literature, I found no systematic effect of adjustment lending on growth. (A recent paper by Przeworski and Vreeland [2000] reviews the long inconclusive literature on the IMF, whereas they themselves find a negative effect controlling for selection bias. Some internal World Bank and IMF studies have found positive effects of their programs on growth. I do not intend to make the effect of structural adjustment on growth a major focus of the paper, because structural adjustment would of course alleviate poverty if it raised growth and worsen it if it lowered growth.) Of course, behind this zero average result is concealed a set of expansions and contractions that depended in part on the particulars of the adjustment program in each country and time period. In general, we would expect that an adjustment program would disfavor some sectors that were previously artificially protected or subsidized and favor other sectors that benefit from a change in relative prices in their favor. Whether expansion or decline dominates depends in part on the relative sizes of the expanding and declining sectors (as pointed out by Rauch [1997]). 
Table 11.2

Regression Results on Change in Poverty, Growth, and Adjustment Programs

\begin{tabular}{|c|c|c|c|c|c|c|}
\hline \multirow[b]{2}{*}{ Variable } & \multicolumn{2}{|c|}{$\begin{array}{c}\text { Ordinary Least } \\
\text { Squares: Regression } 1\end{array}$} & \multicolumn{2}{|c|}{$\begin{array}{c}\text { Ordinary Least } \\
\text { Squares: Regression } 2\end{array}$} & \multicolumn{2}{|c|}{$\begin{array}{c}\text { Two-Stage Least } \\
\text { Squares: Regression } 3\end{array}$} \\
\hline & Coefficient & $t$-statistic & Coefficient & $t$-statistic & Coefficient & $t$-statistic \\
\hline $\mathrm{C}$ & 0.039 & 1.82 & 0.319 & 4.68 & 0.381 & 4.23 \\
\hline GROWTH & -1.892 & -8.24 & -5.481 & -8.27 & -5.452 & -4.67 \\
\hline GINI1 & & & -0.006 & -3.83 & -0.006 & -3.65 \\
\hline PROGRAM & & & -0.019 & -0.62 & -0.114 & -1.31 \\
\hline GROWTH*GINI1 & & & 0.058 & 3.27 & 0.057 & 2.68 \\
\hline GROWTH*PROGRAM & & & 1.790 & 7.37 & 2.027 & 3.49 \\
\hline$N$ & 149 & & 144 & & 126 & \\
\hline
\end{tabular}

Variable definitions

GROWTH Log rate of growth per annum in mean of household survey

GINI1 Initial Gini coefficient

PROGRAM Number of IMF/World Bank adjustment loans initiated per annum

CENTAM Dummy for Central America

FRZ Dummy for Franc Zone

EGYPT Dummy for Egypt and Israel

SSA Dummy for Sub-Saharan Africa

LAC Dummy for Latin America

ECA Dummy for Eastern Europe and Central Asia

EASIA Dummy for East Asia

LGDPPC Log of initial per capita income (Summers-Heston)

Notes: Dependent variable: Log rate of change per annum in percent of population below $\$ 2$ per day. Instruments for PROGRAM: CENTAM EASIA EGYPT FRZ SSA LAC ECA GROWTH, CENTAM $\times$ GROWTH, EASIA $\times$ GROWTH, FRZ $\times$ GROWTH, EGYPT $\times$ GROWTH, SSA $\times$ GROWTH, GINI $1 \times$ GROWTH, LAC $\times$ GROWTH, ECA $\times$ LGDPPC.

The result on expansions strongly reducing the rate of poverty-or output crises raising the rate of poverty - is familiar from other studies (Ravallion and Chen 1997; Dollar and Kraay 2000; Bruno, Ravallion, and Squire 2000; Lustig 2000; Ravallion 2000). Without controlling for other variables, the mean growth elasticity of poverty is about 1.9 (table 11.2).

The significant coefficient on the interaction term between the Gini coefficient and the growth rate also confirms the Ravallion (1997) and Bruno, Ravallion, and Squire (2000) result (table 11.2). Ten percentage points higher Gini will lower the growth elasticity of poverty by 0.6 percentage points. A not-often-noticed implication of this result is that the poor will be hurt less by output contraction in a highly unequal economy than in a relatively equal one, simply because the poor have a low share of output to begin with. The initial Gini also has a direct negative effect on the change in poverty, suggesting a reversion to greater equality if a country begins highly unequal.

The new result in this paper is that, although adjustment lending has no direct effect on poverty reduction, it has a strong interaction effect with eco- 


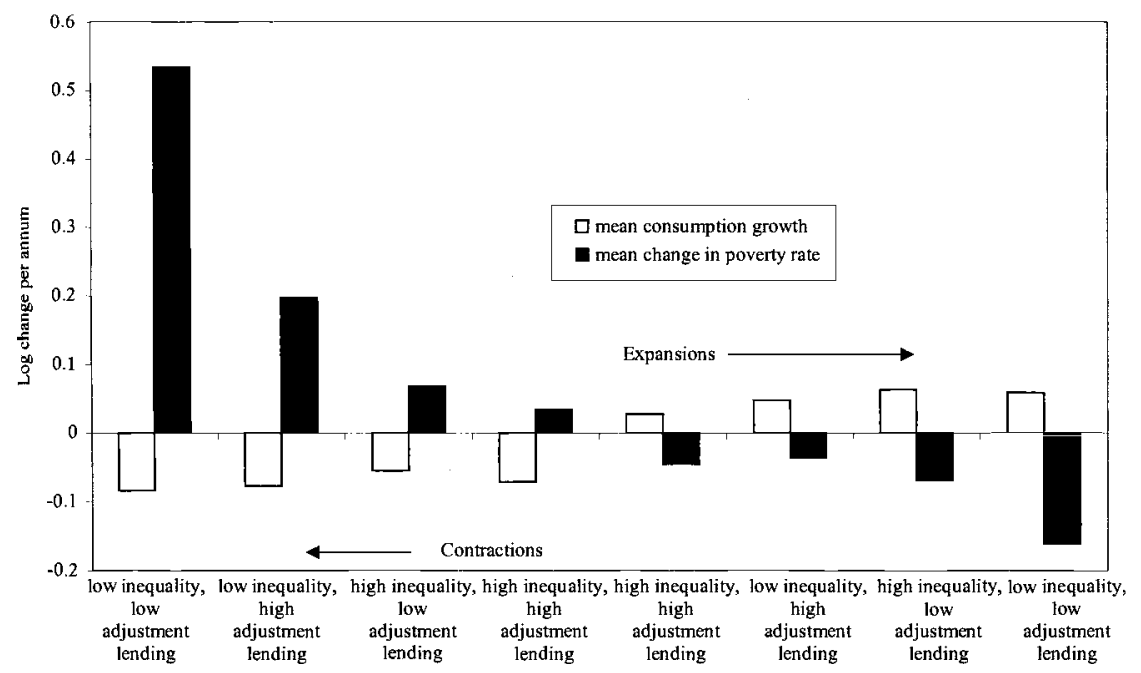

Fig. 11.1 Contractions and expansions, with varying levels of inequality and adjustment lending

nomic growth (table 11.2). ${ }^{2}$ The absolute value of the growth elasticity of poverty declines by about two points for every additional IMF or World Bank adjustment loan per year. The results are strong either in ordinary least squares (OLS) or instrumenting for World Bank and IMF programs with the instruments shown. The instruments for selection bias are plausibly exogenous, and they do a sufficiently good job explaining World Bank and IMF programs that I still obtain a significant result when using these instruments.

This means that the poor benefit less from expansions during a structural adjustment program than in expansions without an adjustment program, while they are at the same time hurt less by contractions. Expansion under adjustment lending is less pro-poor, whereas contraction under adjustment lending is less anti-poor. The welfare of the poor may have increased from the income-smoothing effect of adjustment lending.

On the other hand, it is disappointing that the poor do not share fully in growth in those cases in which there are recoveries that accompany adjustment lending. Because the World Bank and the IMF ultimately wish to restore growth in the economies to which they make adjustment loans, it is worrisome that positive growth has less of a poverty-reducing impact with high World Bank IMF involvement.

Figure 11.1 illustrates the results. Countries with a low level of adjust-

2. IMF (1999) found that "In seven SAF/ESAF countries for which data are available, poverty rates declined by an average of 20 percent under IMF-supported adjustment programs, implying an average annual reduction of 5.3 percent." This study did not control for mean growth. 
ment lending (AL) as measured by PROGRAM and low inequality have both greater increases in poverty during contraction and greater falls in poverty during expansions than do countries with a high level of IMF and World Bank lending and high inequality. (The terms high and low AL here simply mean the upper and lower 50 percent of the sample as measured by the number of programs per year; expansion is the average of all increases in mean income, and contraction is the average of all decreases in mean income).

Another way of illustrating the weakened link between growth and poverty reduction with high inequality and high adjustment lending is to calculate the number of perverse outcomes in quartiles of the sample defined by high and low inequality and high and low adjustment lending. A perverse outcome is defined as either a mean expansion with an increase in poverty or a mean contraction with a decrease in poverty. Such perverse outcomes are rare except in the case in which both inequality and adjustment lending are high, when they account for 27 percent of the sample (figure 11.2).

What is the marginal impact on poverty of IMF and World Bank adjustment loans? If we specify a counterfactual of zero adjustment lending to all countries in the sample, we find that the effect of the actual adjustment loans on the number of poor was a net increase of 14 million. This represents an increase of 0.4 percentage points in the population-weighted average poverty rate in the sample. The outcome reflects the net effect of an increase in the number of poor compared to the counterfactual of no

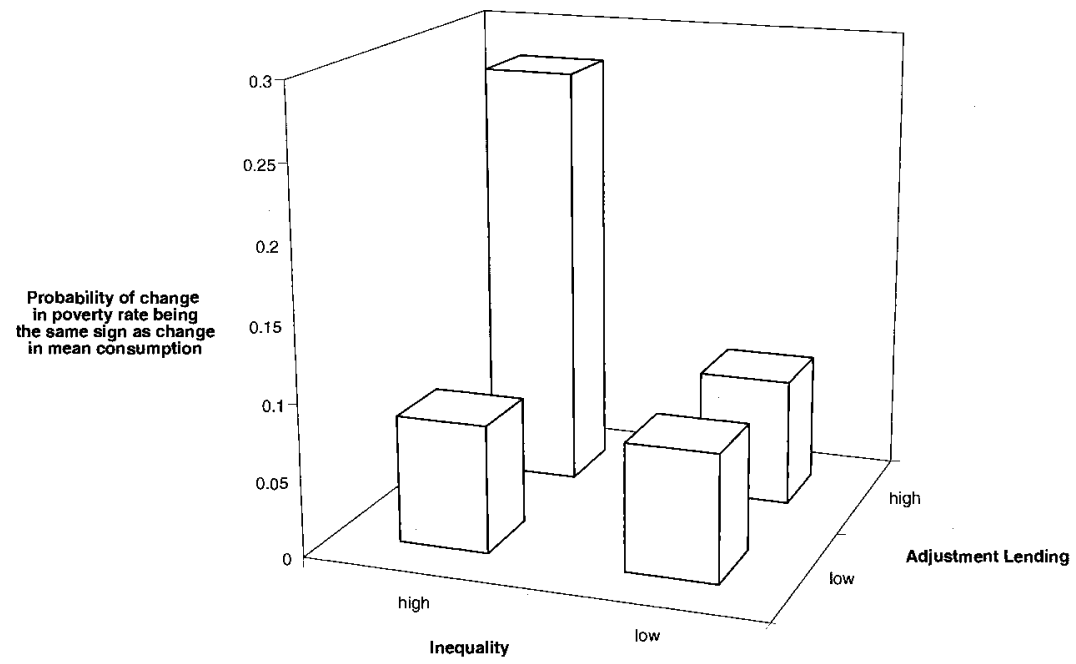

Fig. 11.2 Probability of perverse poverty-growth outcomes depending on level of inequality and adjustment lending 


\section{Table 11.3}

Poverty Elasticities with Respect to Growth for Different Gini Coefficients and Adjustment Loan Intensity

\begin{tabular}{lccc}
\hline & \multicolumn{3}{c}{ Number of Adjustment Loans } \\
\hline Gini coefficient & 0 & 0.5 & 1 \\
30 & -3.8 & -2.7 & -1.7 \\
45 & -2.9 & -1.9 & -0.9 \\
60 & -2.1 & -1.0 & 0.0 \\
\hline
\end{tabular}

Note: Number of adjustment loans is average per year during survey period.

adjustment loans in growing countries like India, ${ }^{3}$ whereas there was a decrease in poverty compared to the counterfactual in contracting countries like Russia and Ukraine. The unweighted median change in the poverty rate associated with adjustment loans is 0.0 .

Table 11.3 uses the coefficients from regression (2) to calculate the poverty elasticity with respect to growth at different levels of the Gini coefficient and adjustment loans per year (AL). The middle cell is close to using the average value for Gini and AL, and we reproduce the familiar elasticity of 2. However, there is great fluctuation around this average for different measures of the Gini and AL. If there are no adjustment loans and inequality is very low, then poverty is extremely elastic with respect to growth (3.8). China in 1990-92 is an example of an observation that would approximately fall in this cell. At the other extreme, a highly unequal country receiving adjustment loans sees no effect of growth or contraction on poverty. Colombia in 1995-96 is an example of a country that would roughly fit in this cell.

I performed several robustness checks on these results. First, I looked for asymmetries between expansion and contraction in both growth effects and the interaction term with adjustment lending. I found no evidence for any asymmetries - the interaction term between adjustment lending and growth remains statistically significant in the separate samples of expansions and contractions.

Second, I added the initial poverty rate both in levels and as an interaction term. The initial poverty rate enters with a negative sign in levels-indicating some tendency of poverty to revert to the mean-but it leaves the significance of the interaction term between adjustment lending and growth unchanged.

Third, I entered the mean household consumption from the household survey, both in levels and as an interaction term with growth. It left the coefficient on the growth and adjustment program interaction unchanged in

3. Even though India and China received only a small number of adjustment loans (in China's case, all in the 1980s), removal of even this small number of loans still has a large effect because of their large populations. 
magnitude and significance, whereas the mean household consumption was not significant either in levels or as an interaction term with growth.

Fourth, one might think that what matters is the total size of the adjustment loan. I try controlling for the flow of resources under IMF and World Bank loans in addition to the number of loans. The interaction of this resource flow with growth is insignificant, whereas the significance of the interaction between number of adjustment loans and growth remains significant.

Fifth, there is a common conception that the content of IMF and World Bank conditions has changed over time, away from straight macroeconomic adjustment and toward more structural reform that may have helped the poor more. A priori, this is unlikely to be an important factor, because the bulk of the poverty spells in my sample start after the mid-1980s (only 13.5 percent of the sample has a start date before 1986). This was after the IMF had moved from pure standby operations to longer-term adjustment lending, and the World Bank always stressed structural measures. In any case, I find that if I split the sample into the period before and after 1989, which is the median start date of the poverty spells in the sample, there is no difference in results between the two subperiods.

Sixth, I try omitting transition countries from Eastern Europe and the former Soviet Union. I find no change in the pattern of results.

Given all the interest in currency crises, I examine the four currency crisis cases that are in the present sample: Mexico (1989-95), Indonesia (1996-99), Russia (1996-98), and Thailand (1996-98). All of them had at least one adjustment loan per year during the period before and during the crisis (table 11.4). Growth was negative in all cases, but the increases in poverty were fairly modest except for Indonesia. We should not make much out of four data points in a sample of 126 observations (and certainly there are too few data to dummy them out as a group), but it is still interesting to see if we can explain the differential poverty response to currency-output crises with the regression. We can understand Mexico's low poverty-growth elasticity as reflecting its high inequality and its receipt of adjustment loans. Thailand's near-zero poverty-growth elasticity could be rationalized as a consequence of its high adjustment intensity and its relatively average rate of inequality. Indonesia fits the story with a slightly below average elasticity associated with low inequality but relatively intense adjustment lending. Russia is an outlier, with a high elasticity despite an extraordinarily high number of adjustment loans per year.

\subsection{Testing the Countercyclicality of Adjustment Lending}

One possible explanation for the poverty-smoothing effect of adjustment lending may be that conditionality on macro adjustment is tougher during expansions than contractions, because the IMF and World Bank may fear 


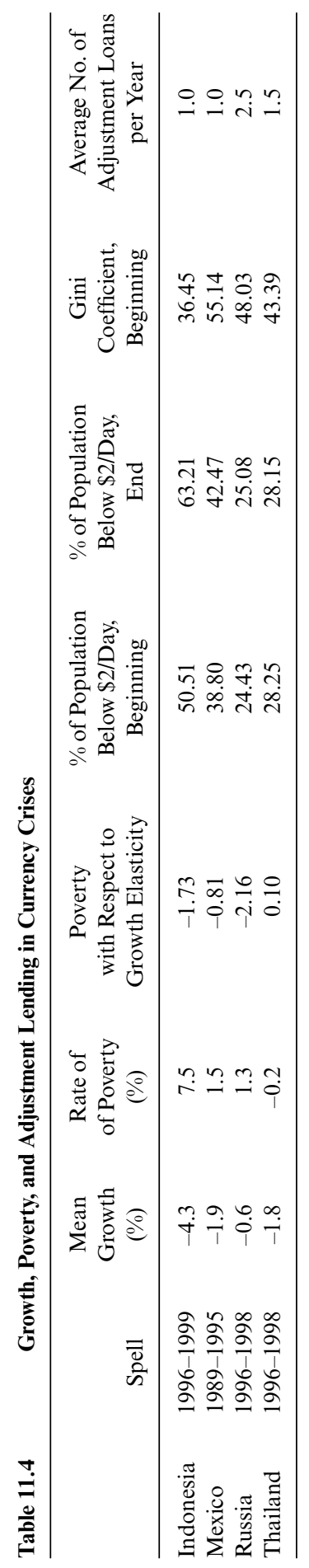


deepening a contraction with excessive austerity. If the poor disproportionately suffer from austerity, then in contractions they will suffer less for a given rate of mean income decline, while, conversely, they will do less well for a given rate of growth in expansions. Second, the principal means of fiscal adjustment under adjustment programs during expansions may be through regressive taxation measures like sales taxes, which lower the benefits to the poor of mean income growth. Third, World Bank and IMF lending programs may explicitly include "social safety nets" that cushion the effect of a contraction on the poor, whereas these transfers may be reduced during expansions. I will first test for countercyclicality of these variables and then test their effect on the poverty rate.

Table 11.5 tests the countercyclicality of adjustment lending by presenting means of macro and fiscal policy variables for quartiles of the sample divided between expansions and contractions and between high and low adjustment lending. We find some evidence for countercyclicality of adjustment lending. Inflation is above average during contractions under high adjustment lending, suggesting that conditions on monetary growth and domestic credit expansion may be less tough if the economy is otherwise experiencing a contraction. (There could also be reverse causation from above-average inflation to economic contraction, but then why does this not show up under low adjustment lending?) Most interesting of all, transfers are significantly above average during contractions under adjustment lend-

Table 11.5 Deviations of Policy Variables from Long-Run Averages under Expansions and Contractions with Different Levels of Adjustment Lending ( $t$-statistics in italics)

\begin{tabular}{lcccc}
\hline & $\begin{array}{c}\text { Expansion and } \\
\text { High-Adjustment } \\
\text { Lending }\end{array}$ & $\begin{array}{c}\text { Expansion and } \\
\text { Low-Adjustment } \\
\text { Lending }\end{array}$ & $\begin{array}{c}\text { Contraction and } \\
\text { High-Adjustment } \\
\text { Lending }\end{array}$ & $\begin{array}{c}\text { Contraction and } \\
\text { Low-Adjustment } \\
\text { Lending }\end{array}$ \\
\hline Black market & \multicolumn{2}{c}{ Macro } & Policies (Log Deviations) & \\
premium & $-6.7 \%$ & $-7.3 \%$ & $-6.2 \%$ & $5.4 \%$ \\
Inflation & -1.61 & -2.45 & -1.09 & 0.94 \\
& $-0.7 \%$ & $0.4 \%$ & $6.9 \%$ & $6.3 \%$ \\
Real exchange rate & -0.72 & 0.21 & 2.63 & 0.61 \\
& $-13.7 \%$ & $-4.1 \%$ & $-14.5 \%$ & $-0.3 \%$ \\
Real interest rate & -4.90 & -1.36 & -3.68 & -0.06 \\
& $0.0 \%$ & $2.9 \%$ & $2.5 \%$ & $-3.1 \%$ \\
Budget surplus & 0.02 & 0.94 & 0.64 & -0.46 \\
& & Fiscal Policies $(\%$ of GDP) & & \\
Transfers & 0.28 & 0.67 & 0.63 & 0.18 \\
& 0.39 & 2.10 & 1.40 & 0.26 \\
Taxes on domestic & -0.57 & 0.00 & 0.86 & -0.18 \\
goods and services & -1.94 & 0.01 & 2.44 & -0.45 \\
\hline
\end{tabular}

${ }^{a}$ Negative indicates depreciation. 
ing, whereas they are significantly below average during high-AL expansions; there is no such countercyclical behavior of transfers under low adjustment lending. Other macro and fiscal policy variables do not show significant deviations from the means in the quartile subsamples.

Table 11.6 does various tests of the equality of means across the quartiles displayed in table 11.5. Under high adjustment lending, I confirm that inflation and transfers are significantly higher under contractions than under expansions, again reinforcing the possibility of countercyclicality of monetary and fiscal policy under adjustment lending.

There are some other interesting differences in means. The black market premium moves countercyclically under low adjustment lending - low during expansions and high during contractions. Causation here could run in both directions, but what is important for the poor is the pattern of cyclical covariation. Adjustment lending eliminates this countercylicality, which would tend to smooth consumption of the poor if they suffer disproportionately from high black market premiums.

The other strong pattern that emerges is that adjustment lending is associated with a more depreciated real exchange rate, regardless of whether mean consumption is expanding or contracting. This is no doubt because devaluation is often a condition of IMF programs. There may also be reverse causation from currency collapses to the initiation of World Bank and IMF adjustment loans. Devaluation itself may be expansionary or contractionary (Gupta, Mishra, and Sahay 2000), perhaps depending on the size of the initial current account imbalance and the currency denomination of public and private debt relative to the tradables intensity of those who owe the debts.

So there is some evidence that adjustment lending has countercyclical effects in ways that may smooth the consumption of the poor. However, is there direct evidence that these effects account for the lower growth elasticity of poverty under adjustment lending? Unfortunately, it is difficult to find evidence that these policy variables are responsible for smoothing poverty under adjustment lending. The three examples of variables for which adjustment lending altered the cycle - inflation, the black market premium, and fiscal transfers - do not show any direct effect on poverty, either directly or interacted with growth (table 11.7). Entering these variables leaves the interaction effect of growth and adjustment lending on poverty unchanged.

Easterly and Fischer (2001) find some evidence that inflation increases poverty, when inflation is measured in absolute terms rather than relative to country averages. They also find that the poor are more likely than the rich to mention inflation as a top national problem in opinion surveys. Because of the difference in methodology, I do not think the results of table 11.7 contradict the Easterly-Fischer results on the effects of inflation on poverty. I interpret the inflation deviation as a measure of the cyclical component of 


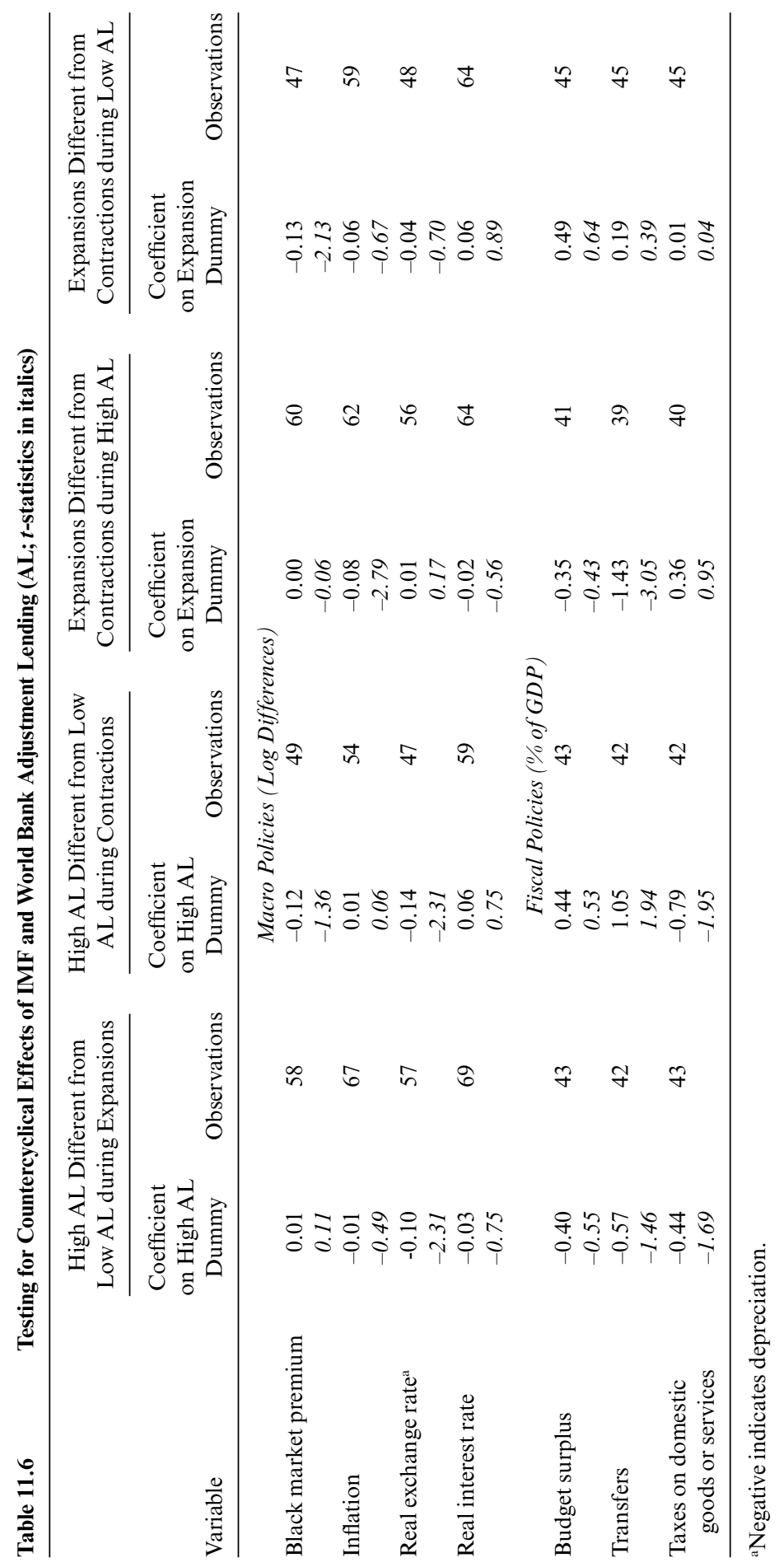


Regression of Poverty Rate on Possible Mechanisms for Poverty Smoothing through Adjustment Lending

\begin{tabular}{|c|c|c|c|c|c|c|}
\hline \multirow[b]{2}{*}{ Variable } & \multicolumn{2}{|c|}{ Regression 1} & \multicolumn{2}{|c|}{ Regression 2} & \multicolumn{2}{|c|}{ Regression 3} \\
\hline & Coefficient & $t$-statistic & Coefficient & $t$-statistic & Coefficient & $t$-statistic \\
\hline $\mathrm{C}$ & 0.010 & 1.00 & 0.006 & 0.64 & 0.020 & 1.46 \\
\hline GROWTH & -5.086 & -6.36 & -4.252 & -5.72 & -7.654 & -5.57 \\
\hline GINI1*GROWTH & 0.076 & 4.35 & 0.055 & 3.20 & 0.127 & 4.21 \\
\hline GROWTH*PROGRAM & 0.713 & 2.13 & 0.752 & 2.13 & 1.180 & 2.57 \\
\hline GROWTH*PIDEV & -0.930 & -1.17 & & & & \\
\hline PIDEV & -0.028 & -0.62 & & & & \\
\hline GROWTH*BMPDEV & & & -1.200 & -1.50 & & \\
\hline GROWTH*TRANSFERS & & & & & -0.088 & -0.57 \\
\hline TRANSFERS & & & & & -0.004 & -0.35 \\
\hline$N$ & 99 & & 91 & & 65 & \\
\hline
\end{tabular}

$\begin{array}{ll}\text { New variables } & \\ \text { PIDEV } & \text { Deviation of log inflation from average 1980-98 } \\ \text { BMPDEV } & \text { Deviation of log black market premium from average 1980-98 } \\ \text { TRANSFERS } & \text { Deviation of transfers/GDP from average 1980-98 }\end{array}$

Notes: Dependent variable: log change in poverty rate. Method: two-stage least squares. Instrument list: C GROWTH GINII CENTAM EASIA EGYPT SSA GROWTH, CENTAM $\times$ GROWTH, EASIA $\times$ GROWTH, EGYPT $\times$ GROWTH, SSA $\times$ GROWTH, LAC $\times$ GROWTH, FRZ $\times$ GROWTH, ECA LGDPPC LAC ECA FRZ LPOP GROWTH, LPOP $\times$ GROWTH.

inflation that may be altered by IMF and World Bank adjustment lending. This cyclical component of inflation doesn't seem to have an effect on the $\log$ change in the poverty rate, in contrast to the negative effect of very high absolute inflation on the poor.

The message of table 11.7 is consistent with the alternative hypothesis mentioned at the beginning of the paper. The kind of macroeconomic and fiscal policy measures that the World Bank and IMF usually support may themselves cause an expansion or contraction in the aggregate economy, depending on the composition of adjustment packages. However, these policies may not affect the poor very much because the poor derive much of their income from the informal sector or subsistence production. I do not test this hypothesis directly, but I adduce a few illustrative bits of information. First, I show that there is a strong cross-section association between measures of the size of the informal sector (taken from Enste and Schneider 1998 ) and the poverty rate (using the same poverty data on percent below $\$ 2$ per day). ${ }^{4}$ The scatter diagram is presented in figure 11.3.

The statistical association is very strong, as shown in table 11.8. One per-

4. I include Enste and Schneider's informal sector size for the ten richest economies in the world and assume their poverty rate is zero. The association is just as strong leaving out the rich economies, however. I am grateful to Arup Banerjee for pointing out this data source and the association between poverty rates and the size of the informal sector. 


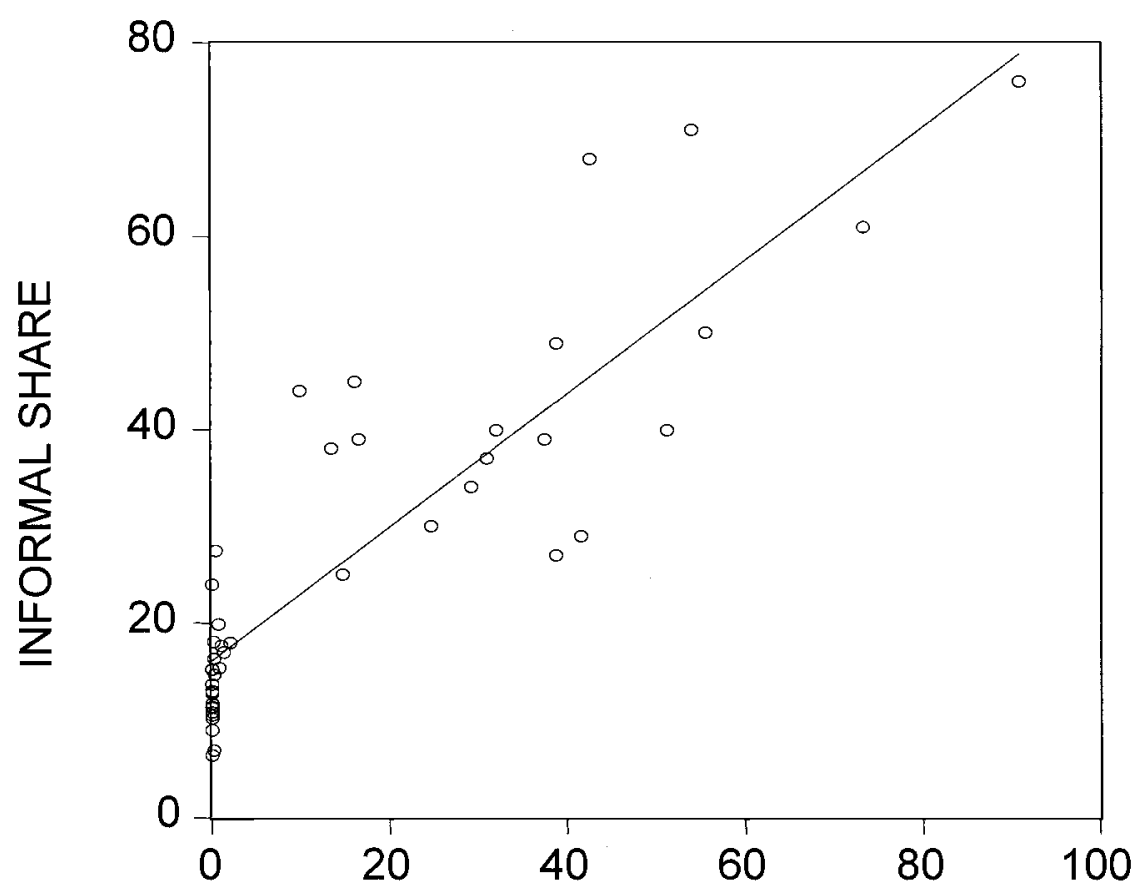

\section{POVERTY RATE}

Fig. 11.3 Association between poverty rate and share of informal sector

centage point more of the population below $\$ 2$ a day is associated with 0.7 more percentage points of the population in the informal sector. This evidence suggests that the poor are indeed in the informal sector.

This cross-section evidence is confirmed with fragmentary data from household surveys that show that the poor derive much of their income from informal and subsistence income. I offer a suggestive example from Zambia and Burkina Faso in table 11.9. Self-employment income is extremely important for the poorest deciles in Zambia. The bias is less extreme in Burkina Faso, but the poorest still have their earnings skewed toward self-employment income. These surveys are suggestive of the importance of the informal sector for the poorest households, lending credence to the relative insulation of the poor from structural adjustment measures.

Lipton and Ravallion $(1995,2601)$ stress that there is considerable heterogeneity within the urban informal sector, with an individual's poverty depending more on individual attributes like human capital than on any economywide labor market distortion leading to the creation of an infor- 
Table 11.8

Regression of Informal Sector Share on Poverty Rate

\begin{tabular}{lcccr}
\hline Variable & Coefficient & Standard Error & $t$-statistic & Prob. \\
\hline C & 16.10031 & 1.679363 & 9.587155 & 0.0000 \\
POVERTY_RATE & 0.690322 & 0.059128 & 11.67513 & 0.0000 \\
$R^{2}$ & 0.768765 & & & \\
Adjusted $R^{2}$ & 0.763125 & & & \\
S.E. of regression & 8.900320 & & & \\
Sum squared resid. & 3247.843 & & & \\
Log likelihood & -153.9921 & & & \\
Mean dependent var. & 27.64651 & & & \\
S.D. dependent var. & 18.28715 & & & \\
Akaike info criterion & 7.255447 & & & \\
Schwarz criterion & 7.337363 & & & \\
$F$-statistic & 136.3087 & & & \\
Prob. $(F$-statistic) & 0.000000 & & & \\
\hline
\end{tabular}

Notes: Dependent variable: INFORMAL_SHARE. Method: least squares. Included observations: 43 .

Table 11.9 Sources of Income: Percent Share by Income Decile, from Poorest to Richest

\begin{tabular}{|c|c|c|c|c|}
\hline \multirow[b]{2}{*}{$\begin{array}{l}\text { Income } \\
\text { Decile }\end{array}$} & \multicolumn{2}{|c|}{ Zambia Household Survey } & \multicolumn{2}{|c|}{ Burkina Faso Household Survey } \\
\hline & $\begin{array}{l}\text { Profits and } \\
\text { Self-Employment } \\
\text { Income }\end{array}$ & Wages & $\begin{array}{l}\text { Profits and } \\
\text { Self-Employment } \\
\text { Income }\end{array}$ & Wages \\
\hline 1 & 100 & 0 & 42 & 58 \\
\hline 2 & 99 & 1 & 32 & 68 \\
\hline 3 & 94 & 6 & 21 & 79 \\
\hline 4 & 67 & 33 & 19 & 81 \\
\hline 5 & 45 & 55 & 17 & 83 \\
\hline 6 & 17 & 83 & 15 & 85 \\
\hline 7 & 12 & 88 & 18 & 82 \\
\hline 8 & 11 & 89 & 21 & 79 \\
\hline 9 & 10 & 90 & 27 & 74 \\
\hline 10 & 36 & 64 & 46 & 54 \\
\hline
\end{tabular}

Sources: Devarajan (2000).

mal sector. Other distortions may exclude the poor from taking advantage of reforms under structural adjustment, like lack of access to credit. Van de Walle (2000) shows evidence of lower return to formal-sector investments (irrigation in her specific example) for the less educated. Lundberg and Squire (2000) find that the bottom quintile is the only quintile not to benefit from trade openness. The poor may be geographically isolated from the formal-sector economy, which may be exacerbated by poor infrastructure. Whatever the distortion or initial endowment at work, the individuals who are poor may be ill placed to take advantage of new opportunities created 
by structural adjustment programs, just as they may suffer less from the destruction of old opportunities enjoyed by protected sectors prior to structural adjustment.

The effect of IMF and World Bank structural adjustment programs on policies, as mandated from the top, is usually limited to a few highly visible macroeconomic indicators - like the fiscal balance and devaluation (expenditure-reducing and expenditure-switching policies). Again, these seem more likely to affect the formal than the informal sector. In economies growing under home-grown reform programs, where government ownership of the program creates stronger motivation for genuine change, the transformation of incentives is likely to be economywide-stimulating both the informal and formal sectors. China in the 1990s is a good example of home-grown reform without adjustment lending, although it was open to advice from international financial institutions (IFIs). China reduced the percent living on less than $\$ 2$ a day from 71 percent in 1990 to 50 percent in 1998. Chile 1987-1994 is another example of rapid reduction in poverty with an indigenous reform program and very little adjustment lending. Despite high inequality, the percent living on less than $\$ 2$ a day in Chile fell from 31 in 1987 to 20 in 1994. El Salvador is an example of an economy going in the other direction, with economic expansion and intensive adjustment lending, but seeing poverty actually increase over this period.

\subsection{Conclusions}

The results in this paper are suggestive that IMF and World Bank adjustment lending provides a smoothing of consumption for the poor, lowering the rise in poverty for a given contraction, but also lowering the fall in poverty for a given expansion. Adjustment lending seems to play a similar role to inequality in lowering the sensitivity of poverty to the aggregate growth rate of the economy.

The lower sensitivity of poverty to growth under adjustment lending is bad news during expansions and good news during contractions. If we think of the normal steady state of the economy as being one of positive growth, then adjustment lending is bad news for the growing economy; it means the poor share less in the expansion of the economy. One might think that adjustment lending happens only during non-steady-state output crises. It could also be that adjustment lending hurts the poor in the short run but helps them in the long run by raising growth. Unfortunately, there is little evidence of adjustment lending's raising growth in the long run. This is a question that has been intensively studied, with few convincing results. The bare facts are not supportive. There were thirty-six countries that the IMF and World Bank gave ten or more adjustment loans over 1980-98. The median growth rate of income per person in this group over the past two decades was zero (which is also the median growth rate of the entire developing-country sample, and of the sample of poverty spells in this paper). 
Adjustment lending has been so continuous for some economies that it is hard to speak of it as purely a transitional phenomenon. This continual dependence on the IFIs, requiring in some cases relief from past IFI loans, is itself cause for concern. If adjustment loans had to be repeated ten times or more, this clearly does not speak well of the effectiveness of the treatment.

From a political economy point of view, lowering the sensitivity of poverty to the aggregate growth rate could be dangerous because it gives the poor less of a stake in overall good economic performance. This might increase the support of the poor for populist experiments at redistributing income.

These results could be interpreted to give support to either the critics or the supporters of structural adjustment programs. To support the critics, growth under structural programs is less pro-poor than in economies not under structural adjustment programs. To back the supporters, contractions under structural adjustment hurt the poor less than contractions not under structural adjustment programs.

The question that further research should pursue is why structural adjustment lending reduces the sensitivity of poverty to growth. Although there is evidence that adjustment lending alters the cycle for some policy variables, there is no evidence that these alterations affect poverty.

I speculate that the poor depend more on the informal sector, which is not directly affected as much as the formal sector by economic reforms under adjustment loans. More generally, the poor may be ill placed to take advantage of new opportunities created by structural adjustment reforms, just as they may suffer less from the loss of old opportunities in sectors that were artificially protected prior to reforms. The poor may also benefit more from sweeping home-grown reform programs than those in which the government reforms are limited to a few highly visible indicators constrained by IMF and World Bank adjustment loans. A recent World Bank report on aid and reform in Africa found no relationship between adjustment lending (or aid more generally) and the development of such a broad consensus (Devarajan, Dollar, and Holmgren 2001). As this report puts it, "successful reformers have consultative processes that result in a broad consensus for reform."

One distinction that should be made is between "structural adjustment lending" and "structural adjustment policies." This paper has tested the effect of the former but not the latter. There is considerable international evidence that structural adjustment policies, like macroeconomic stabilization, financial development, openness to trade, and removal of price distortions, improve growth potential - and thus strengthen poverty reduction. ${ }^{5}$ However, the success of adjustment loans at changing policies is very mixed. The tests for this paper found a strong effect only for the real

5. The literature on this subject is vast. See Easterly and Levine (2001) for a demonstration that good policies matter for growth. 
exchange rate. The IMF noted in 1995 that the "record of achieving . . low inflation" under its programs in low-income economies "was at best mixed." Half of those with IMF programs had inflation go down and half had it go up (Schadler 1995, 39). For example, Zambia had eleven adjustment loans from 1985 to 1996, but it had inflation above 40 percent for every one of those years except two. This pattern is part of the more general historical record that foreign aid and adjustment lending have not discriminated much between good and bad policies. As the World Bank $(1998,48)$ notes, "there is a long legacy of failed adjustment lending where there was no strong domestic constituency for reform." It may be that structural adjustment measures succeeded in changing only a few token indicators, like the real exchange rate, that affected mainly the formal sector, but left the economywide pattern of incentives otherwise untouched.

The results may not be so surprising in view of the recent vintage of the concern for poverty in IMF and World Bank adjustment packages, well after the poverty spells that make up most of my sample. In other words, for most of the period, IMF and World Bank adjustment lending was not designed to reduce poverty directly, and so it is not surprising that they were not unusually effective at doing so. The results of adjustment lending may change as the IFIs emphasize more poverty reduction under adjustment lending. Alternatively, the results may suggest that adjustment loans are not a very effective vehicle for reducing poverty, and the IFIs and the government would do better by directing resources toward programs that directly target poverty. These could include income subsidies for the poor, infrastructure targeted toward poor areas, improved access to credit (possibly through microcredit schemes), subsidies for inputs to subsistence production, and improved access to market information (such as through information technology) for the poor.

An aggregate result like this is a useful guide for further research. Further research should probably take the form of more detailed case studies like those in Devarajan, Dollar, and Holmgren (2001). If we think of a matrix that has on one dimension good or bad policies, and on the other dimension adjustment lending or not, we could examine cases from each of the four cells. These cases could examine the interrelationship among adjustment lending, country ownership, policy reform, targeted poverty measures, growth, and poverty reduction. 


\section{Appendix}

Table 11A.1 Countries with Poverty Spells, 1980-99

\begin{tabular}{|c|c|c|c|}
\hline Country & \# Spells & Country & \# Spells \\
\hline Algeria & 1 & Mali & 1 \\
\hline Bangladesh & 4 & Mauritania & 2 \\
\hline Belarus & 3 & Mexico & 2 \\
\hline Brazil & 5 & Moldova & 1 \\
\hline Bulgaria & 3 & Morocco & 1 \\
\hline Chile & 3 & Nepal & 1 \\
\hline China & 8 & Niger & 1 \\
\hline Colombia & 3 & Nigeria & 2 \\
\hline Costa Rica & 3 & Pakistan & 3 \\
\hline Czech Republic & 1 & Panama & 4 \\
\hline Dominican Republic & 1 & Paraguay & 1 \\
\hline Ecuador & 2 & Peru & 2 \\
\hline Egypt & 1 & The Philippines & 4 \\
\hline El Salvador & 2 & Poland & 4 \\
\hline Estonia & 2 & Romania & 2 \\
\hline Ethiopia & 1 & Russia & 3 \\
\hline Ghana & 2 & Senegal & 1 \\
\hline Guatemala & 1 & Slovakia & 1 \\
\hline Honduras & 4 & Slovenia & 1 \\
\hline Hungary & 1 & Sri Lanka & 2 \\
\hline India & 10 & Thailand & 4 \\
\hline Indonesia & 5 & Trinidad and Tobago & 1 \\
\hline Ivory Coast & 5 & Tunisia & 1 \\
\hline Jamaica & 4 & Turkey & 1 \\
\hline Jordan & 2 & Turkmenistan & 1 \\
\hline Kazakhstan & 2 & Uganda & 1 \\
\hline Kenya & 1 & Ukraine & 3 \\
\hline Korea & 1 & Uzbekistan & 1 \\
\hline Kyrgyzstan & 2 & Venezuela & 5 \\
\hline Latvia & 3 & Yemen & 1 \\
\hline Lesotho & 1 & Zambia & 2 \\
\hline Lithuania & 3 & Grand total & 155 \\
\hline Madagascar & 1 & & \\
\hline Malaysia & 4 & & \\
\hline
\end{tabular}

Source: Ravallion and Chen 1997 (updated by the authors). 


\section{References}

Bruno, Michael, Martin Ravallion, and Lyn Squire. 2000. Equity and growth in developing countries: old and new perspectives on the policy issues. In Distributive justice and economic development: The case of Chile and developing countries, ed. Andres Solimano, Eduardo Aninat, and Nancy Birdsall, 37-65. Ann Arbor: University of Michigan.

Devarajan, Shanta. 2000. A macroeconomic framework for poverty reduction strategies. World Bank. Mimeograph.

Devarajan, Shanta, David Dollar, and Torgny Holmgren. 2001. Aid and reform in Africa: Lessons from 10 case studies. Washington, D.C.: World Bank.

Dollar, David, and Aart Kraay. 2000. Growth is good for the poor. World Bank. Mimeograph.

Easterly, William, and Stanley Fischer. 2001. Inflation and the poor. Journal of Money, Credit, and Banking 33 (2, part 1): 160-78.

Easterly, William, and Ross Levine. 2001. It's not factor accumulation: Stylized facts and growth models. World Bank Economic Review 15:177-219.

Enste, Dominik, and Friedrich Schneider. 1998. Increasing shadow economies all over the world: Fiction or reality? IZA Discussion Paper no. 26. December. Munich, Germany.

Gupta, Poonam, Deepak Mishra, and Ratna Sahay. 2000. Output response during currency crises. International Monetary Fund and World Bank. Mimeograph.

International Monetary Fund (IMF). 1999. The IMF and the poor. Pamphlet Series no. 52. Washington, D.C.: International Monetary Fund.

Lipton, Michael, and Martin Ravallion. 1995. Poverty and policy. In Handbook of Development Economics, vol. 3B, ed. Jere Behrman and T. N. Srinivasan, 2551658. Amsterdam: Elsevier.

Lundberg, Mattias, and Lyn Squire. 2000. The simultaneous evolution of growth and inequality. World Bank. Mimeograph.

Lustig, Nora. 2000. Crises and the poor: Socially responsible macroeconomics. Economia 1 (1): Washington, D.C.: Brookings Institution.

Przeworski, Adam, and James Vreeland. 2000. The effect of IMF programs on economic growth. Journal of Development Economics 62:385-421.

Rauch, James. 1997. Balanced and unbalanced growth. Journal of Development Economics 53 (June): 41-66.

Ravallion, Martin. 1997. Can high-inequality developing countries escape absolute poverty? Economics Letters 56 (1): 51-57.

- 2000. Growth, inequality, and poverty: Looking beyond averages. World Bank. Mimeograph.

Ravallion, Martin, and Shaohua Chen. 1997. What can new survey data tell us about recent changes in distribution and poverty? World Bank Economic Review $11(2)$.

Schadler, Susan. 1995. IMF conditionality: Experience under stand-by and extended arrangements. IMF Occasional Paper no. 128. Washington, D.C.: International Monetary Fund, September.

Van de Walle, Dominique. 2000. Are returns to investment lower for the poor? $\mathrm{Hu}-$ man and physical capital interactions in rural Vietnam. World Bank Policy Research Working Paper no. 2425. Washington, D.C.: World Bank.

World Bank and International Monetary Fund. 2001. Fighting poverty and strengthening growth in low-income countries. Joint memorandum of the president of the World Bank and the managing director of the International Monetary Fund. Development Committee no. DC 2001-011. 18 April. 
Comment Edwin M. Truman

\section{Introduction}

William Easterly's paper on the impact of International Monetary Fund (IMF) and World Bank structural adjustment programs on poverty should be troubling to most readers because he believes he has found evidence of an adverse effect of adjustment lending on the link between growth and poverty. However, serious questions can be raised about his methodology and the interpretation of his results.

This paper is about adjustment lending by the international financial institutions (IFIs); it is not about structural adjustment lending by those institutions. The author inappropriately, in my view, uses results about the former to criticize the latter. Easterly states that critics may conclude "growth under structural adjustment programs is less pro-poor than in economies not under structural adjustment programs." On the other hand, supporters of such programs may conclude that "contractions under structural adjustment hurt the poor less than contractions not under structural adjustment programs."

It is important to understand what he finds: (a) growth reduces poverty, (b) adjustment lending has "no direct effect on poverty reduction," and (c) adjustment lending "has a strong interaction effect with economic growth," which means, in his words, that "the poor benefit less from expansions during a structural adjustment program than in expansions without an adjustment program, while they are at the same time hurt less by contractions." It is the third statement that is the focus of the paper.

It is more surprising that Easterly finds a positive statistical association between adjustment lending and dampening the effect of growth on poverty during downturns than that he finds a positive statistical association between adjustment lending and dampening of the effect of growth on poverty during an expansion. My prior would have been that adjustment lending was associated with relatively bad times, and the lower the growth rate in those bad times, the larger the impact on poverty.

The issue of the impact of adjustment lending on poverty is important. For that reason we should hold research on this topic to a high standard. The basic problem with this paper is that Easterly does not succeed in establishing the reason that an absence of adjustment lending should produce a larger impact of growth on poverty. The reader is left with two alternative explanations: First, adjustment lending does not affect the very poor because they are more often part of the informal economy. This is interesting,

Edwin M. Truman is a senior fellow at the Institute for International Economics.

Comment by Edwin M. Truman on chapter 11, "IMF and World Bank Structural Adjustment Programs and Poverty" by William Easterly is (C) 2001, Institute for International Economics. 
but not very useful. Second, a distinction is made between home-grown reform programs and programs mandated from outside the country. This distinction is not well supported by the facts. International financial institutions do not require members to borrow from them. Members come to them precisely when their policies have failed or continue to fail. It is Easterly's apparent lack of appreciation of this distinction that contributes to his misunderstanding of the nature of the selection bias that undermines his statistical results.

\section{What is a Structural Adjustment Lending Program?}

A major problem with Easterly's paper is that it adopts a broad and misleading definition of structural adjustment lending by the IFIs. It is wrong to lump essentially all types of IMF lending together with various types of World Bank structural adjustment lending for purposes examining the impact of IFI structural adjustment lending programs. International Monetary Fund and World Bank lending to support structural adjustment in member economies differs from lending to support macroeconomic stabilization. The former involves an attempt to attack some of the deeper problems that have affected the performance of these economies. Easterly is careful to distinguish in his conclusions between structural adjustment lending and structural adjustment policies, but he is not careful in his statistical analysis to distinguish between adjustment lending and structural adjustment lending, and he uses the two terms interchangeably in the main body of his paper. This is unfortunate when much of the current debate is about the structural content of IFI lending.

Easterly's lending data go back to 1980 , when the conditionality in most IMF programs was aimed simply at macroeconomic stabilization and had little to do with structural considerations. As is reported in the recent IMF review of structural conditionality in programs (International Monetary Fund 2001), less than one-fifth of the upper credit tranche standby and extended arrangements approved in 1985 and 1986 had any performance criteria related to structural measures. As a consequence, in its recent review the IMF's data on its structural conditionality do not start until 1987; the big surge in such lending was after 1994. Goldstein (2001) also documents this point.

It is true that by 1980 the IMF had its Extended Fund Facility (which dates from 1974), but the Structural Adjustment Facility was not established until 1986. It is also true that the World Bank has made structural adjustment loans for many years, but most of the loans for a good part of the 1980s were merely disguised balance-of-payments loans. In other words, Easterly should have sorted out the true from the ersatz structural adjustment loans from the Bretton Woods institutions before he started his statistical analysis. It is not enough, in my view, just to split the sample at 1989.

Second, even in the case of lending by the IFIs that all would agree was 
focused primarily on achieving structural objectives, those objectives come in various shapes and sizes. For example, what would we expect to be the impact on poverty of a program directed at restructuring the financial system of a member country? We would expect very little impact one way or another, but other factors (omitted variables) meanwhile may produce Easterly's statistical correlations. What about loans directed at reducing pricing distortions or rationalizing tariff structures? We would expect more of an impact, and we should be interested in the sign, but we should question whether the impact would be statistically similar across countries.

Third, structural adjustment lending has many different objectives, depending in large part on the circumstances of the members. Structural adjustment lending for a country in transition (Russia and Ukraine) differs from structural adjustment lending for an emerging-market economy (Korea or Thailand). Structural adjustment lending in Africa today also differs from such lending (primarily) to Latin American countries in the late 1980s and early 1990s. It is misleading to expect that lending to countries in substantially different amounts and circumstances will be associated with similar effects in a broad statistical analysis. Moreover, structural adjustment programs differ in size and in their degree of emphasis on structural adjustment; a better variable to try to capture the impact of such programs would be the size of the program in special drawing rights (SDR) or dollars per capita rather than just the number of programs approved by the IMF and World Bank executive boards. Easterly reports that he tried to control for any interaction effect with the absolute size of loans, but it was insignificant, whereas the interaction effect with the number of loans remained significant. This is puzzling, as is the fact that there was no multicollinearity problem in the estimation. One is left wondering whether the statistical results are dominated by a large number of small loans to a large number of small countries.

Fourth, it is important to worry about the contemporaneous impact of adjustment lending on poverty and to try to design programs that at a minimum cushion those impacts, but any significant positive payoffs from this type of program, one would expect, would be felt with a considerable lag after the lending occurs. Adjustment lending programs are not known as sources of instant gratification. Structural adjustment, in particular, is a complex process that even at its most effective normally has effects over time. Easterly compounds this problem by his use of "poverty spells" (pairs of substantially similar poverty surveys) of different lengths and treating them as identical dependent variables. Moreover, as Easterly notes, in many instances adjustment programs are of different lengths, efforts may not be sustained, and the lending programs may be suspended or cancelled. One might expect these differences to affect the results. It is disturbing that a researcher as serious and respected as Easterly did not take the time to refine his data.

In summary, my major criticism of this paper is that it combines apples, 
oranges, grapes, tomatoes, pasta, potatoes, red meat, and raw fish. It is not too surprising that the result is not particularly appetizing. We should be surprised that there are any "statistically significant" results at all.

\section{Counterfactual and Other Methodological Issues}

In addition to Easterly's misleading categorization of IFI adjustment lending programs, his paper raises serious methodological issues, some familiar to students of this literature and some less so. The familiar issue is the potential bias in the selection of the countries that have and have not had any or much lending from the IFIs. What we have is a problem of the counterfactual or control group. It is unfortunate in this connection that the reader is not provided with a full cross-classification of so-called adjustment lending with the "poverty spells." We are told in passing that India and China are countries that have had few or no such loans and Russia and Ukraine had a large number.

I commented above about the inappropriate inclusion of lending to the latter two countries in the sample, but how are we to think about China and India? Calling China's economic reform program "home-grown" is a distortion of the facts. Over the past twenty years, China has undergone a great deal of structural adjustment, often under the close tutelage of the IFIs. Moreover, China received three adjustment loans from the IFIs during the 1980s. China had two standby arrangements with the IMF in which the Chinese authorities laid out in considerable detail their reform plans. ${ }^{1}$ India, on the other hand, has undergone very little structural adjustment, and many observers wring their hands about the Indian situation. India had a substantial IMF program in the early 1990s, and it is generally regarded as a success.

My basic point is that Easterly does not seriously address the statistical problem of selection bias; his use of instruments drawn from the foreign aid literature does not do the trick. The issue is not which countries may have had a political leg up to help to obtain IFI financial assistance, but the nature of their economic and financial circumstances that drove them to seek assistance from the IFIs. Building a convincing statistical counterfactual is a complex issue, but researchers must try harder to come to grips with it in studies of this nature.

Second, researchers know a lot about IFI programs, and it is troubling, for example, when Easterly lists a number of speculations about what the IMF or World Bank may "fear" about contractions, or what "may be" the nature of a change in taxation that was part of a program, or what "may"

1. Chile (1987-94) is another poor example of a home-grown adjustment program unsupported by IFI lending. Chile economic programs during this period were drawn up in close cooperation with the IMF and World Bank, and the only reason that they did not receive financial support from those institutions through most of that period was political. 
have been included with respect to social safety nets when these are facts that are known or knowable.

Third, macroeconomic conditions have a lot to do with what is going on in the background with adjustment programs, but the amount of macroeconomic analysis in this paper is limited to a look at the countercyclicality of IFI lending. No attempt is made there to control for economic circumstances (for example, external financial difficulties) in the actual statistical tests; no attempt is made to differentiate trend from cycle. On the other hand, Easterly was careful to split his sample between periods with contractions and periods with expansions to see if there is a statistical difference in his interaction term.

Fourth, it would be useful to know more about the 150 (more or less) data points. Although Easterly summarizes the data, the reader would like to know more in order to evaluate his results. He makes much of the distinction between "poverty spells" during which there are expansions and those in which there are contractions in income or consumption. (Disconcertingly, the two concepts are used interchangeably.) We are told that median consumption growth is zero, the mean is -1.1 percent, and the standard deviation is 11.1 percent, but that is not a lot of information. Figure 11.2 provides summary information on perverse poverty-growth outcomes (expansions associated with increases in poverty, or contractions associated with a decline in poverty) sorted on the basis of the level of inequality and adjustment lending. In the cell with high inequality and high adjustment lending, 27 percent of the observations are perverse. This strikes one as rather significant, but we are not told whether the perversity is evenly distributed between expansions and contractions.

Finally, Easterly tries to tease out of his data set information on four instances of currency crisis: Indonesia, Mexico, Russia, and Thailand. He does not "make much" (his words) of the data points. Each case involved a contraction (negative growth) and an above-average amount of adjustment lending according to Easterly's crude definition. He notes, almost in passing, that "the increases in poverty were fairly modest except for Indonesia." In fact, the ex post elasticities for the four cases range from -2.16 to 0.1 , compared with the estimated average of -1.9 . Moreover, the mean of these four observations is -1.1 , three standard deviations below the mean in the total sample. It would appear that on average in these four cases that involved heavy doses of structural adjustment lending, the so-called damping effect of such lending, through whatever mechanism, was unusually pronounced.

This type of gross cross-section analysis has provided policy makers with valuable insights in the past, when the work is carefully done. One can appreciate the challenge involved in enriching the data used for this type analysis, but in this case, too much useful and relevant information has been discarded or ignored. 


\section{Results and Policy Implications}

What implications for policy should we draw from this paper?

First, Easterly generates a statistical result that adjustment lending appears to dampen the effect of growth (expansion or contraction) on poverty without, in my view, establishing a convincing story or mechanism that might produce this effect. He acknowledges that doing so is crucial to his analysis, but the issue is not fully resolved by his paper. He finds that adjustment lending alters the cycle for some policy variables, but he also finds no evidence that these alterations affect poverty. Without a convincing mechanism, one worries about correlation without causation.

Second, the author's concluding remarks on the issue of a mechanism focus on the informal sector and suggests that adjustment lending is irrelevant to poverty alleviation because the poor are largely found in the informal sector. This is a rather narrow view of both poverty and adjustment lending. It is one thing to think that adjustment in an economy, no matter how defined or supported, has a minimal direct and immediate impact on the informal sector and, therefore, on poverty, but that is not the same as being irrelevant. In the longer run, the overall efficiency of the economy does matter because we expect that as a consequence of growth the poorest will move from the informal sector to the formal sector.

Third, it is useful to be reminded that, even in cases of classical stabilization programs that are supported by IFI lending, attention should be paid to the impact on poverty. However, in some cases, a country has been living beyond its means, and the growth of and, sometimes, even the level of aggregate expenditure needs to be curbed or reduced to restore overall balance to the economy. If this occurs evenly across income classes, poverty will increase. The question for the policy maker is whether the distribution of expenditure can be twisted even as the overall level or growth is adjusted. It is a reasonable goal, and one that deserves attention, but the near-term objective in programs undertaken in the context of overall economic stabilization efforts is to try to avoid expenditure cuts that have a disproportionate impact on the poorest, even though, as Easterly concedes, these are "recent vintage" concerns, and maybe not the best grounds for criticizing IFI lending over the past twenty years.

Fourth, in structural adjustment programs, appropriately defined, attention to details is even more important. It should not be difficult to improve the efficiency of existing programs ostensibly intended to assist the poorest while reducing their overall cost, because too many of such programs are not really directed at reducing poverty but rather at subsidizing the middle class, if not the upper class. The challenge to do better is not always easy to meet, in particular at a time of crisis, when the design phase of structural programs is compressed. Nevertheless, we know what has to be done. Take, 
for example, the matter of subsidized petroleum product prices in oilproducing countries. From an overall efficiency standpoint, the cost of the subsidy involved is often outrageous. Nevertheless, political leaders are reluctant to reduce the subsidy substantially and appeal to resistance by the poor to justify their reluctance when the true political resistance comes from a broader and more politically active segment of the population. The objective should be to design programs to rationalize petroleum product prices and use some of the fiscal savings to address more directly and effectively the needs of the poor, at the extreme, for example, via direct income transfers.

Finally, do we conclude from Easterly's paper that there should be more or less structural adjustment lending by the IFIs? There is an active debate on this issue, especially within the IMF, as we know from Goldstein (chap. 8 in this volume), although that debate focuses not so much on support for structural adjustment as on which IFI should take the lead. On the basis of this paper, we are justified in concluding that (a) the issue of the impact on poverty and the poor needs to be further researched and (b) the overall effectiveness of such lending needs to receive greater scrutiny.

The author states that for many of the countries in his sample "adjustment lending has been so continuous ... it is hard to speak of it as purely a transitional phenomenon." Whether one is talking about macroeconomic adjustment or structural adjustment properly defined, prolonged access to the IFIs is a problem for the countries because they are falling further behind, for the IFIs themselves because they are failing in their missions, and for the system as a whole because support for rational policies and instruments is being undermined. This paper does not help to advance that worthy agenda. It certainly does not add much to the debate when Easterly rests part of his criticism of prolonged use on the fact that the median growth rate of income per person in a group of thirty-six heavy IFI borrowers over the period 1980-98 was zero because the median consumption growth per household in his overall sample of sixty-four countries was also zero.

Easterly argues that "structural adjustment policies" promote poverty reduction but implies that "structural adjustment lending" by the IFIs in support of those policies is counterproductive. This is a rather curious distinction to make. To make it on the basis of a contrast between so-called home-grown programs and programs mandated from the top (of the IFIs or the borrowing governments) just does not hold water. It displays an incomplete understanding of IFI lending programs over the past twenty years; countries face external financial or other deep-seated economic difficulties and turn, with varying degrees of success, to the IFIs for financial and policy assistance. Researchers will have to come to grips better with those realities in their statistical analyses if they are to deal adequately with the problem of selection bias in studies of this type. 
Easterly is right that more careful and detailed research needs to be done on these important matters, but I do not believe that his aggregate results yet provide much of a useful guide for further research.

\section{References}

Goldstein, Morris. 2001. IMF structural conditionality: How much is too much? IIE Working Paper no. 01-4. Washington, D.C.: Institute for International Economics, April.

International Monetary Fund. 2001. Structural conditionality in IMF-supported programs. Washington, D.C.: International Monetary Fund. 16 February.

\section{Discussion Summary}

Morris Goldstein suggested that the World Bank's mandate was poverty reduction but that the IMF did not share this mandate. He therefore concluded that it is not clear why IMF loans were included and why they should be relevant to the poor.

Olivier Blanchard noted that there is a need to consider the elasticity of poverty with respect to the trend and the cyclical component of growth separately. These might be different, so this differentiation suggests a different explanation for the paper's findings - possibly that cyclical growth has less effect on poverty rates.

Jeffrey Shafer questioned why the paper assumed that the programs should affect poverty relative to economic growth. It is not within the IMF's mandate, after all. One needs, he noted, to examine whether there actually is an effect on poverty that is separate from the effect on growth. In any case, he concluded, there is a role for IFIs that is independent of their poverty reduction rhetoric.

Martin Feldstein pointed to the fact that the official line of both institutions is poverty reduction; therefore, it is essential to examine whether they actually do what they say they do.

Jeffrey A. Frankel suggested that the IMF most likely mitigates downturns and increases long-run growth and only thus decreases poverty. While one hopes all this is true, it remains unclear whether there is an effect on income distribution that is separate from the growth channel.

Lant Prichett, using the analogy of a sheriff's role in maintaining order, argued that the IMF's role should not be measured by its effect on program countries only but rather by its effect on the international system of payments as a whole.

William Easterly responded that much of the criticism of the IMF and World Bank claims that structural adjustment increases poverty, and so it is 
relevant to consider the effect of adjustment loans on poverty both through the growth channel and through other channels. He also stated that the results probably do not reflect the effect of adjustment loans (ALs) on longrun growth and poverty because the poverty spells measure used is mostly for short-term data. He noted, as well, that opponents of the World Bank and IMF might misuse these results but that this possibility should not affect research conducted even within those institutions.

Martin Eichenbaum and Edwin M. Truman suggested that instead of using program dummies it might prove fruitful to include the size of programs (in absolute levels or per capita), because bigger programs should have stronger effects than very small ones. Michael Dooley concluded that if cycles are symmetric and ALs are indeed cutting down volatility, then the effect is beneficial for the poor. 
